UDC 661.183; 661.634

\title{
ACID-BASE PROPERTIES OF PHOSPHORUS-CONTAINING POLYMERIC SORBENT ON THE BASIS OF POLYBUTADIENE- STYRENE RUBBER
}

\author{
N.A. Efendiyeva*, A.A. Azizov*, G.A. Nagkhiyev**, R.M. Alosmanov*, \\ I.A. Bunyad-zadeh* \\ *Baku State University \\ Z.Xalilov str., 23, Baku AZ 1148, Azerbaijan Republic, e-mail:r_alosmanov@rambler.ru \\ **LTD «National Center for Nuclear Research» \\ Inshaatchilar ave., 4, Baku AZ 1073, e-mail: info@mntm.az
}

Recieved 14.09.2018

\begin{abstract}
The acid-base properties of functional-analytical groups of polymeric sorbent based on butadienestyrene rubber were investigated. The polyfunctionality of the explored sorbent was proved out by the potentiometric titration method and $p K_{\text {ion }}$ values of functional-analytical groups were calculated: $p K_{1}=4.924 ; p K=9.429$.
\end{abstract}

Keywords: butadiene-styrene rubber, polymeric sorbent, sorption capacity, oxidative chlorophosphorylation

\section{INTRODUCTION}

It is indisputable that with ever growing development of industry, the removal of heavy metal ions and toxic organic substances polluting the environment attracts heightened attention of the public to make up one of the main problems of the ecosystem. Usually, heavy metals are found in the large amounts in industrial waste waters. Moreover, most of them have specific toxic properties, and are stable pollutants with a cumulative effect. This adversely affects all living organisms and creates serious health problems, even if detected at very low concentrations [1].

Therefore, the removal of heavy metals from wastewaters becomes the subject of considerable interest of inventors. As is known, traditional methods for removal of heavy metal water medium can be accomplished through various treatment options, including reagents treatment, ion exchange, membrane operations and etc. [2-6]. As for the modern technology of water purification, the adsorption technique attracts main attention due to its availability and simplicity. As a rule, in adsorption processes of water treatment and purification the various inorganic and organic materials, including polymers,are used. Phosphorus-containing polymers are one of the widely used among polymer materials [7].

It should be noted that the reaction activity of polymer sorbents and stability of obtained polymer salts predetermine the efficiency of sorption process and the interphase ions distribution in the polymer matrix and water solution. On the other hand, the quantitative description of inorganic groups' dissociation immediately gives rise to sorption properties' investigations.

The article presents paper the results of investigations into acid-base properties of phosphorus-containing polymeric sorbent (PhPS) on the basis of changing (modifying, varying) potentiometric titration curves in the sorbent/solution system. 


\section{EXPERIMENTAL}

\section{Materials}

PhPS was obtained by means of oxidative chlorophosphorylation of butadienestyrene rubber (obtained from Voronezh

Synthetic Rubber Manufactory, Russia) and further hydrolysis of the obtained modifier by the well-known procedure [8]. Note that $\mathrm{HCl}$, $\mathrm{NaCl}, \mathrm{NaOH}$ were used without additional purification.

Determinati on of static sorption capacity of sorbent towards $\mathrm{Na}$ ion

Sorbents sorption capacity depends on the number of functional groups in the polymer and $\mathrm{pH}$ of solution. Samples of sorbent with 0.1 geach were weighed on analytical scales following which $20 \mathrm{ml}$ of 0.1 $\mathrm{N} \mathrm{NaOH}$ solution was added to each of them. Samples of polymer in the solution were kept for 24 hoursand then filtrated. Note that $2.5 \mathrm{ml}$ of solution was taken from each of filtrate and titrated with $0.1 \mathrm{NHCl}$ in the presence of a few drops of indicator - $1 \%$ water solution of phenolphthalein.

The value of $\mathrm{SSC}_{\mathrm{Na}}{ }^{+}\left(\mathrm{mg}\right.$-eqv $\left.\cdot \mathrm{g}^{-1}\right)$ was calculated by the equation below:

$$
\mathrm{SSC}_{\mathrm{Na}^{+}}=\frac{\left(200 F-\frac{200}{25} V F_{1}\right) \cdot 0.004 \cdot 1000}{40 \mathrm{~g}}=\frac{200 F-8 V F_{1}}{10 g}
$$

where $\mathrm{F}$ is the correlation coefficient on $0.1 \mathrm{~N}$ $\mathrm{NaOH} ; \mathrm{V}$ is the volume of $0.1 \mathrm{NHCl}$ used during the titration, $\mathrm{ml} ; \mathrm{F}_{1}$ is the correlation coefficient on $0.1 \mathrm{~N} \mathrm{HCl} ; 0.004$ is the titer of $0.1 \mathrm{~N} \mathrm{NaOH}$; 40 is the molecular weight of $\mathrm{NaOH}$ andg is the sorbent mass, g. The obtained results were used for determination of functional groups' ionisation constants.

\section{Calculation of ionisation constants (pK)of} functional groups. Pothentiometric titration

The accuracy of this method generally depends on the degree of sorbent purification, as well as the accuracy of the exchange capacity determination, the set up equilibrium between solid and liquid phases upon the $\mathrm{pH}$ measurement and the correct selection of electrode pairs. It'd be appropriate to emphasize that the potentiometric titration is carried out with the use both of one andseveral samples.

Sorbent samples of $50 \mathrm{mg}$ in $\mathrm{H}$-form were weighed on analytical scales for titration using the method of separate weighing and placed in $50 \mathrm{ml}$ flask. Ionization constant value depends largely on ionic effect of solution. As the ionic effect rises, the value of the ionisation constant does the same. Therefore the value of the dissociation constant must be determined at a constant ionic effect of the solution to reachconstant ion force values of $20 \mathrm{ml}$ of $2 \mathrm{M} \mathrm{NaCl}$.

Then different quantities of $0.025 \mathrm{M} \mathrm{NaOH}$ were added to each of bottles. The necessary quantity of $\mathrm{NaOH}$ was determined so that the value of full neutralisation degree of functional groups $Q$ changed in a range of 0 up to $\mathrm{SSC}_{\mathrm{Na}}{ }^{+}(\mathrm{Q}$ was calculated as the ratio of added alkali amount (mmol) to the total number of functional analytical groups (mmol) of the sorbent). Then the bottles with solutions were stirred by nitrogen and kept in the nitrogen filled exsiccator at ambient temperature in order to reach the ionic equilibrium and then $\mathrm{pH}$ of solutions have been measured.

\section{RESULTS AND DISCUSSION}

Following our examination it became possible to establish that the value of sorbent's $\mathrm{SSC}_{\mathrm{Na}}{ }^{+}=6.5 \mathrm{mq} \cdot \mathrm{eqv} / \mathrm{g}$. On the basis of potentiometric titration data the integral curves in $\mathrm{pH}-\mathrm{Q}$ (where $\mathrm{Q}$ is amount of titrant, $\mathrm{mmol} / \mathrm{g}$ ) coordinates were plotted. As a result of graphical differentiation of integral curve, the grafical curve of titration in $\Delta \mathrm{pH} / \Delta \mathrm{Q}-\mathrm{Q}$ coordinates was plotted (Fig.1) to specifythe equvalence point (Fig.1). 


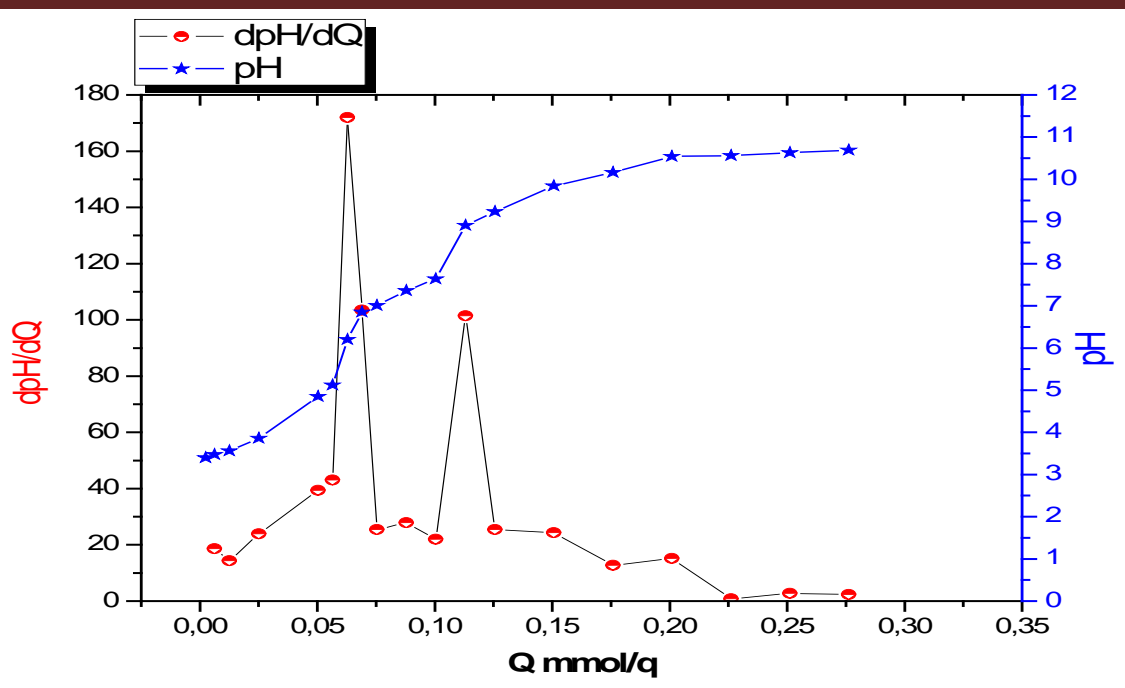

Fig.1. Integral and differential curves of potentiometric titration of sorbent on the basis of butadiene-styrene rubber

As can be seen in Fig.1, the titration curve has a stepwise form that shows the presence of two ionogenic groups in the explored polymer. The value of ionisation degree $(\alpha)$ was calculated by the equation (2) for the analysis of potentiometric titration data:

$$
\alpha=\frac{N \cdot V}{g \cdot C E C_{\mathrm{Na}^{+}}}
$$

where: $\mathrm{N}$ is the normality of $\mathrm{NaOH}$ solution; $\mathrm{V}$ is the extravolume of $\mathrm{NaOH}, \mathrm{ml}$; $\mathrm{g}$ is the weight of sorbent, $\mathrm{g}$.

The calculation of avalue for eachionisation step was carried out to comply with the value of static capacity of functional group into polymer phase, i.e. the ratio of the added $\mathrm{NaOH}$ (mmol) quantity to the total amount (mmol) for each active group in $1 \mathrm{~g}$ of polymer.

The titration curve described dependence of $\mathrm{pH}$ solution on the added amount of $\mathrm{NaOH}$ making it possible to determine the maximum value of sorbent capacity.

Table 1 presents the data for calculation of $\mathrm{pK}_{\text {ion }}$ of synthesized phosphorus-containing sorbents using $\alpha=0.5$ as a point of neutralization in the Henderson - Hasselbach equation:

Table 1. Data for ionization constants' calculation

\begin{tabular}{|c|c|c|c|c|c|}
\hline & $\boldsymbol{\alpha}$ & $\mathbf{1 - \alpha}$ & $\boldsymbol{\alpha} / \mathbf{1}-\boldsymbol{\alpha}$ & $\lg (\boldsymbol{\alpha} / \mathbf{1}-\boldsymbol{\alpha})$ & $\mathbf{p H}$ \\
\hline \multirow{7}{*}{$\mathrm{pK}_{1}$} & 0.100 & 0.900 & 0.111 & -0.95 & 3.40 \\
\cline { 2 - 6 } & 0.200 & 0.800 & 0.250 & -0.60 & 3.47 \\
\cline { 2 - 6 } & 0.300 & 0.700 & 0.429 & -0.37 & 3.56 \\
\cline { 2 - 6 } & 0.400 & 0.600 & 0.667 & -0.18 & 3.86 \\
\cline { 2 - 6 } & 0.500 & 0.500 & 1.000 & 0.00 & 4.85 \\
\cline { 2 - 6 } & 0.600 & 0.400 & 1.500 & 0.18 & 5.12 \\
\cline { 2 - 6 } & 0.700 & 0.300 & 2.333 & 0.37 & 6.20 \\
\cline { 2 - 6 } & 0.800 & 0.200 & 4.000 & 0.60 & 7.01 \\
\hline
\end{tabular}




\begin{tabular}{|c|c|c|c|c|c|}
\hline \hline \multirow{7}{*}{$\mathrm{pK}_{2}$} & 0.100 & 0.900 & 0.111 & -0.95 & 7.36 \\
\cline { 2 - 6 } & 0.200 & 0.800 & 0.250 & -0.60 & 7.64 \\
\cline { 2 - 6 } & 0.300 & 0.700 & 0.429 & -0.37 & 8.91 \\
\cline { 2 - 6 } & 0.400 & 0.600 & 0.667 & -0.18 & 9.23 \\
\cline { 2 - 6 } & 0.500 & 0.500 & 1.000 & 0.00 & 9.84 \\
\cline { 2 - 6 } & 0.600 & 0.400 & 1.500 & 0.18 & 10.16 \\
\cline { 2 - 6 } & 0.700 & 0.300 & 2.333 & 0.37 & 10.54 \\
\cline { 2 - 6 } & 0.800 & 0.200 & 4.000 & 0.60 & 10.56 \\
\hline
\end{tabular}

Although the thermodynamic constants provide more detailed information about the dissociation of acid groups, their calculation is very complicated in most cases. For practical purposes the constants of apparent dissociation can be used. The values of ionization constants $\mathrm{pK}_{\text {ion }}$ of functional analytical groups were calculated on the basis of potentiometric titration results to comply with Henderson Hasselbach modified equation:

$$
p K_{\text {ion }}=p H-m \lg \frac{\alpha}{1-\alpha}(3)
$$



where, $\alpha$ is the neutralization degree of acidic groups of polymer calculated on the basis of potentiometric titration data, mis the constant characterizing the polymeric state of matter. The grafical dependence was plotted in keeping with the calculation of $\alpha$ values and corresponding $\mathrm{pH}$ data (Table1), (Fig.2):

$$
p H=f\left(\lg \frac{\alpha}{1-\alpha}\right)
$$

Fig. 2. Graphical calculation of sorbent's ionisation constant.

Thus, using the method of potentiometric titration it was revealed that phosphonic and phosphoric acids obtained as a result of hydrolysis of the product of chlorophosphorylation of industrial rubber are dissociated in two steps. It was also established that on the each stage of the titration an approximately equal amount of alkali was used. 


\title{
REFERENCES
}

1. Elpiner L. Drinking water: medicoecological and technological problems. Melioration and water economy.1994, no. 2. pp. 12-14. (In Russian).

2. Dabrowski A., Hubicki Z., Podkoscielny P., Robens E. Selective removal of the heavy metal ions from waters and industrial wastewaters by ion-exchange method. Chemosphere. 2004, vol. 56, pp. 91-106.

3. Fu F., Wang Q. Removal of Heavy Metal Ions from Wastewaters: A Review. Journal of Environmental Management. 2011, vol. 92, pp. 407418.

4. Yavuz M., Gode F., Osmert S., Sharma Y. An economic removal of $\mathrm{Cu}^{2+}$ and $\mathrm{Cr}^{2+}$ on the new adsorbents: Pumice and polyacrilonitrile/pumice composite. Chem. Eng. J. 2008, vol. 137, pp. 453-461.

5. Mulder M. Basic principles of membrane technology. Holland, Kluwer Academic Publ. 1996, 450 p.

6. Cushinie C. Removal of metals from wastewater: neutralization and precipitation. New Jersey, Noyes Publ. 1984. 345 p.

7. Magerramov A.M., Azizov A.A., Alosmanov R.M. Organophosphorus ionites. Baku: Bakı Universiteti Publ. 2011, 112 p. (In Azerbaijan).

8. Alosmanov R.M. Reqularities of divinyl rubber oxydative chlorphosphorylation reaction. Kimya Problemleri - Chemical Problems. 2012, no.1, pp. 37-49. ( In Azerbaijan).

\section{BUTADIEN-STIROL KAUÇUKU OSASLI FOSFORTORKIBLI POLIMER SORBENTIN TURSUU-OSAS XASSOLORI}

\author{
N.A. Әfəndiyeva*, A.Ө. Өzizov", C.Ө. Nağıyev", R.M. Alosmanov", İ.A. Bünyadzadə* \\ *Bakı Dövlat Universiteti \\ AZ 1148 Bakl, Z.Xəlilov küç., 23; e-mail: r_alosmanov@rambler.ru \\ ${ }^{* *}$ Milli Nüva Tadqiqatları Markazi QSC \\ AZ 1073,Bakl, İnşaatçılar pr., 4; e-mail: info@mntm.az
}

Butadien-stirol kauçuku asasl polimer sorbentin funksional-analitik qruplarının turşu-əsas xassələri tadqiq olunmuşdur. Potensiometrik titrlama metodu ila tədqiq edilan sorbentin polifunksionalliğ təsdiq olunmus vo funksional-analitik qrupların $p K_{\text {ion }}$ kəmiyyəti hesablanmışdı: $p K_{1}=4.924 ; p K=9.429$.

Açar sözlor: butadien-stirol kauçuku, polimer sorbent, sorbsiya, oksidlaşdirici xlorfosforlaşma reaksiyası

\section{КИСЛОТНО-ОСНОВНЫЕ СВОЙСТВА ФОСФОРСОДЕРЖАЩЕГО ПОЛИМЕРНОГО СОРБЕНТА НА ОСНОВЕ БУТАДИЕН-СТИРОЛЬНОГО КАУЧУКА}

\author{
Н.А. Эфендиева*, А.А. Азизов*, Дж.А. Нагиев**, Р.М. Алосманов*, И.А. Буният-заде* \\ *Бакинский Государственный Университет \\ AZ 1148 Баку, ул. 3.Халилова, 23; e-mail: r_alosmanov@rambler.ru \\ **3АО «Национальный ичентр ядерных исследований» \\ AZ 1073, Баку, пр. Иншаатчьлар, 4; e-mail: info@mntm.az
}

\begin{abstract}
Исследованы кислотно-основные свойства функционально-аналитических групп полимерного сорбента на основе бутадиен-стирольного каучука. Методом потенииометрического титрования доказана полифункииональность исследуемого сорбента и рассчитаны величины $p K_{\text {iоп }}$ функционально-аналитических групп: $p K_{1}=4.924 ; p K=9.429$.

Ключевые слова: бутадиен-стирольный каучук, полимерный сорбент, сорбционная емкость, окислительное хлорфосфорилирование
\end{abstract}

